С.В. ЯГЕЛЮК, В.Ф. ДІДУХ, Р.В. КІРЧУК Луцький національний технічний університет

\title{
ДОСЛІДЖЕННЯ ПРОЦЕСІВ ЗБИРАННЯ ЛЬОНУ ОЛІЙНОГО 3 ВИКОРИСТАННЯМ СТЕБЛОВОЇ ЧАСТИНИ ВРОЖАЮ
}

\author{
С.В. ЯГЕЛЮК, В.Ф. ДИДУХ, Р.В. КИРЧУК \\ Луцький національний технічний університет
}

\section{ИССЛЕДОВАНИЕ ПРОЦЕССОВ УБОРКИ ЛЬНА МАСЛИЧНОГО С ИСПОЛЬЗОВАНИЕМ СТЕБЛЕВОЙ ЧАСТИ УРОЖАЯ}

\author{
S. YAHELYUK, V. DIDUH, R. KIRCHUK \\ Lutsk National Technical University

\section{PICKING UP THE OIL FLAX YIELD WITH THE STEM PART USAGE INVESTIGATION}

\section{https://doi.org/10.36910/6775-2310-5283-2019-12-28}

Мета. Встановити можливість використання стеблової частини врожаю льону олійного, вирощеного в природно-кліматичних умовах Західного Полісся для підвищення ефрективності і екологічної безпечності ї̈ утилізації.

Методика. Для досліджень використовували аналітичні та розрахункові методи. Значення показників отримані експериментально з допомогою сучасних вимірювальних засобів відповідно до діючих нормативно-технічних документів.

Результати. B статті представлені основні результати теоретикоекспериментальних досліджень прочесів збирання та переробки стеблової частини врожаю льону олійного. Запропоновано алгоритм, щзо описує технологічний процес збирання льону олійного з врахуванням фази його стиглості та погодних умов, які впливають на вибір способу збирання та подальшого використання стеблової частини врожаю.При науковому підході льон олійний вважається культурою безвідходного виробниитва, але для території Західного Полісся перешкодою в широкому поширенні льону олійного став високий стеблестій, який може досягати одного метра у довжині. Технології виробництва льону олійного в умовах Західного Полісся недосконалі, також потребують модернізації операції збирання з метою використання всього потенціалу рослини. Основна проблема, яка на сьогоднішній день не вирішена, - спалювання стеблової частини врожаю. Для збереження вирощеного врожаю, запропонована технологія збирання льону з урахуванням фази зрілості $i$ переробки стебел для подальшого вилежування в тресту або виготовлення паливних матеріалів з використанням зернозбирального комбайна вдосконаленої конструкиії.

Очунка споживчих властивостей волокна льону олійного вказує на значний його потенціал, як сировини для текстильної промисловості. Однак, складності, щуо виникають при вилежуванні стебел в тресту, вимагають пошуку нових напрямків використання волокнистої маси, яка формується в прочесі збору льону олійного зернозбиральним комбайном. Відповідно до погодних умов збору і первинної переробки в поточному сезоні і в 
умовах Західного Полісся зі стебел льону олійного можна отримувати якісне коротке неоріснтоване волокно або паливні матеріали циліндричної форми. Для обох випадків обов'язкова операція руйнування стебел.

Наукова новизна. Запропоновано адаптовану до природно-кліматичних умов Західного Полісся технологію комплексної переробки біологічного потенщіалу льону олійного та льону-довгунцю для отримання товарів різного функціонального призначення.

Практична значимість. Запропонована технологія дозволить підвищити ефективність використання льону олійного в умовах Західного Полісся $i$ задовільнить екологічні вимоги.

Ключові слова: льон олійний, стебла, треста, волокно, кліматичні умови, зусилля різання, руйнування, технологї, технічні засоби.

Постановка проблеми у загальному вигляді та її зв'язок з важливими науковими і практичними завданнями. Розвиток органічного виробництва та імплементація законодавчих актів щодо переробки відходів ЄС [1] в Україні передбачає пошук способів і засобів переробки та утилізації непродуктивної частини окремих технічних культур, насамперед льону олійного.

Утилізація спалюванням стеблової частини льону олійного під час збирання - проблема сільськогосподарського виробництва країн Європи. Спалювання є недопустимим в умовах глобального потепління, також воно наносить значну шкоду навколишньому середовищу так як грунти засмічуються волокнистою складовою стебел, яка тривалий час не розкладається. В зв'язку з цим з'являються проблеми якісного використання земельних ресурсів. Під час збирання льону олійного сучасним зернозбиральним комбайном на полі залишаються валки соломистої маси, які мають значні розміри i, як наслідок, довго не перетворюються в тресту шляхом росяного мочіння. Тому доцільно утилізувати стеблову частину врожаю льону олійного шляхом iï переробки в стаціонарі для отримання продукції різного призначення.

Аналіз останніх досліджень, у яких започатковано вирішення проблеми. Науковці ведуть активний пошук способів переробки та утилізації стеблової частини окремих технічних культур. Дослідження споживних властивостей волокна льону олійного, вирощеного в умовах Західного Полісся показали [2, 3], що вони суттєво не відрізняються від властивостей волокна льону-довгунця. Проте, проблема полягає у відсутності технічних засобів для збирання льону олійного з метою використання максимального потенціалу рослини - після відділення насіння забезпечити механізацію процесів утворення трести, своєчасного її підбору та переробки.

Створенням умов підготовки трести 3 стебел льону-довгунця, 3 метою збереження якісних властивостей волокна, приділялась значна увага $[4,5$,$] ,$ 
відповідно до природно-кліматичних умов вирощування. Зокрема, вченими Херсонського НТУ проводились дослідження зі штучного зволоження соломи льону олійного різними хімічними реактивами 3 метою прискорення вилежування трести та підвищення споживних властивостей отриманого короткого неорієнтованого волокна [6]. Але, на сьогодні відсутні дослідження 3 виробництва волокна 3 льону олійного методом росяного мочіння.

Можливим способом вирішення проблеми також $є$ пошук нових видів паливних матеріалів [7, 8 - 11]. Особливістю виробництва паливних матеріалів 3 такої сировини є їх ущільненні відомими методами, а для їх використання необхідно застосовувати відповідні котли. Льон олійний, вирощений на території Західного Полісся, має потужний енергетичний потенціал. Вченими Луцького НТУ проводились дослідження з виготовлення паливних матеріалів у вигляді брикетів з використанням промороженого озерного сапропелю у якості сполучника. Здійснено також дослідження енергетичного потенціалу отриманих зразків та часу їх згорання. [10].

Наявність у паливних матеріалах короткого волокна льону олійного ускладнює процес виготовлення у вигляді пакунків, придатних для спалювання у серійних твердопаливних котлах через значні пружні властивості стебел. Проте, виробництво таких паливних пакунків дозволить використовувати волокно, не придатне для використання у текстильній галузі.

Відсутність спеціалізованих машин для даної культури призводить до значних втрат врожаю. В першу чергу: значне пошкодження стеблової частини урожаю, що унеможливлює у подальшому виділення з неї волокна; пошкодження та втрата насіння; стерня, що залишається на полі, містить волокно і негативно впливає на подальше використання поля; намотки стебел на робочі органи призводять до зупинок комбайна та виведення його з ладу.

Реалізація процесів руйнування стебел льону олійного при його збиранні на насіння зернозбиральним комбайном прискорить перетворення стебел у тресту, а ефективний механічний вплив на стадії переробки трести максимальне виділення короткого неорієнтованого волокна. Дослідження руйнування листостеблових сільськогосподарських матеріалів [12-14] вказують на перспективність руйнування стеблової частини льону олійного механізованими засобами 3 обертовими барабанами [12-14], проте дослідження процесів подрібнення стеблової частини льону олійного, вирощеного в умовах Західного Полісся на сьогодні нема.

Тому, якщо забезпечити переробку стеблової частини льону олійного у визначені терміни, то можна отримати хорошу волокнисту сировину для 
текстильної промисловості. Якщо волокно втратить свою якість, то можна отримати матеріал придатний для виготовлення палива, геотекстилю, будівельного матеріалу та ін. Це буде сприяти вирішенню багатьох екологічних проблем.

Цілі статті. Проведені дослідження мали на меті встановлення можливостей використання стеблової частини врожаю льону олійного, вирощеного в агрокліматичних умовах Західного Полісся для підвищення ефективності і екологічної безпечності іiі утилізації. Об’єкт дослідження процес збирання стебла льону олійного. Предмет - залежність руйнування стебел на умови отримання волокна та формування паливних матеріалів.

Виклад основного матеріалу дослідження 3 повним обгрунтуванням отриманих наукових результатів. Досліджувались сорти Айсберг, Лірина, Орфей, Південна ніч, Сонєчни. Насіння, використане для сівби, відповідало вимогам ДСТУ 2240-93 «Насіння сільськогосподарських культур. Сортові та посівні якості. Технічні умови». Господарська придатність знаходилась в межах 94,0-98,0 \%, ураженість хворобами - 8,2 \%, тобто насіння в усі роки проведення досліджень відповідало першому класу стандарту якості. В період вирощування проводилась обробка посівів гербіцидами «Агрітокс» - 0,7 л/га (проти дводольних бур'янів) та «Арамо» - 2,0 л/га (проти злакових бур'янів). Обробіток землі загальноприйнятий для зони. Попередники - озимі зернові культури. Спосіб сівби рядковий, ширина міжрядь 15 см. Норма висіву 7 млн. схожих насінин на га. Добрива вносили згідно з схемою N45Р60К90.

Збирання льону олійного пов'язане зі стиглістю сільськогосподарської культури i, за умови своєчасного дозрівання насіннєвої частини у фазах ранньої або ранньо-жовтої стиглості, використовують сегментно-пальцеві різальні апарати.

У даних дослідженнях особливу увагу було звернено на величину зусилля різання стебел для трьох положень: окоренкового, середнього та верхівкового. Початкова відносна вологість стебел при цьому складала від 13 $15 \%$ для трести і 21,8 \% стебел у ранній стиглості.

Таким чином, технічні засоби мають передбачати можливість як зрізування стебел льону олійного, так і витягування з грунту (брання).

Щороку на жатку встановлюють оригінальний новий різальний апарат. Збирання розпочинають у ранній жовтій стиглості культури, попередньо обробляючи посіви дискантами. Більш пізні строки дозрівання унеможливлюють збирання зернозбиральним комбайном 3 сегментнопальцевим різальним апаратом.

Складність отримання сировини для волокна з стебел льону олійного 
виникає на етапі його збирання, так як воно знаходиться у прямій залежності від природно-кліматичних умов у даний період, умов отримання трести та достатній кількості технічних засобів.

Стебла льону олійного відрізняються від стебел льону-довгунця розміщенням на них коробочок насіння, довжиною, кореневою системою. Основним чинником, що визначає зусилля брання є вплив погодних умов, які пов'язані з вологістю грунту, його механічним складом і формою кореневища (рис. 1). Чим вища вологість, тим показники зусилля брання стебел знижуються. Це пов'язано з кореневою системою льону, яка має зв'язки 3 грунтовими агрегатами. У зв'язку 3 тим, що зона Західного Полісся характеризується дерново-підзолистими грунтами, то вологість грунту буде визначальною. Так після випадання дощу, вологість поверхневого шару грунту глибиною до 100-150 мм збільшується від 35-40 \% до 50 \% за рахунок насичення вологою від опадів. Відповідно і зусилля брання стебел зменшується, так як бокові корінці льону олійного, вирощеного в умовах Західного Полісся фактично відсутні (рис.1). При цьому бічні корені слабо розвинені, натомість наявний добре розвинений головний корінь. Така особливість спричинена властивостями грунтів та кліматичними умовами вегетаційного періоду.

Як видно з фото, коренева система обох культур фактично ідентична, що вказує на особливості природно-кліматичних умов вирощування льону олійного в умовах Західного Полісся. Підвищений вміст вологи у грунті в період проведення експериментальних досліджень показав, що зусилля витягування стебел льону - довгунця фактично не відрізняється від зусилля витягування стебел льону олійного.

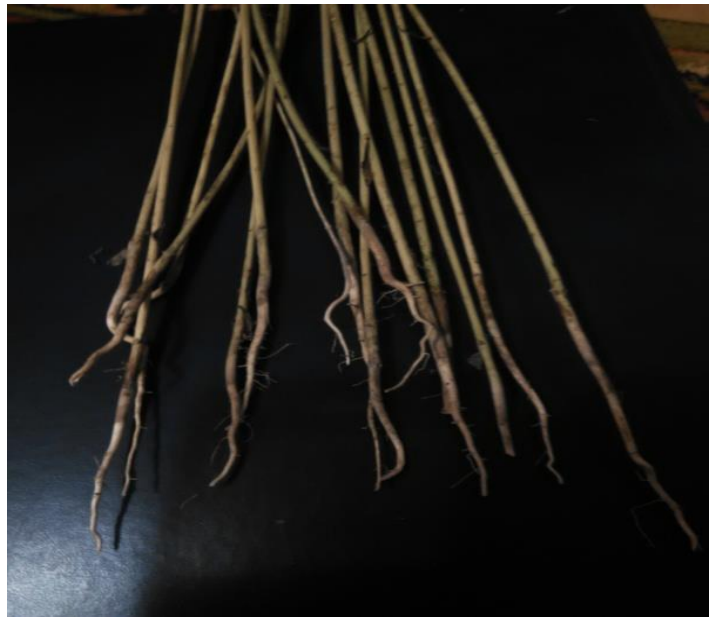

a

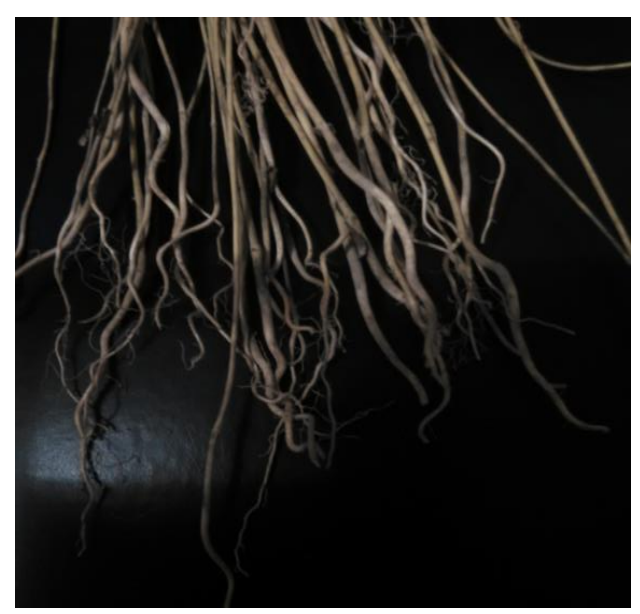

б

Рис. 1. Порівняльні особливості кореневої системи льону-довгунці (а) та льону олійного (б) 
Проблема подальшого перетворення стеблової маси у тресту виникає вже на етапі збирання льону олійного зернозбиральним комбайном (рис. 3), коли на поверхні поля утворюється валок стебел 3 розмірами у поперечному січенні, у межах $1,0 \times 0,5 \mathrm{M}$.

3 рис. 2 видно, що стебла у валках розміщуються хаотично. Це утруднює застосування операції обертання під час їх перетворення у тресту. Також терміни збирання льону олійного залежать від погодних умов i, відповідно буде різна фаза стиглості врожаю. Тому і якість волокна, буде різною.

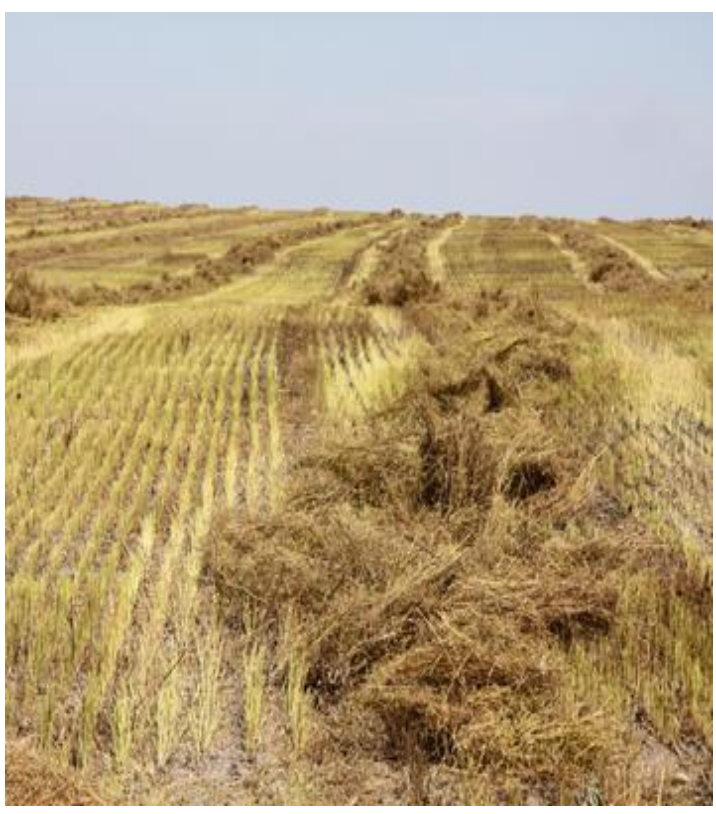

a)

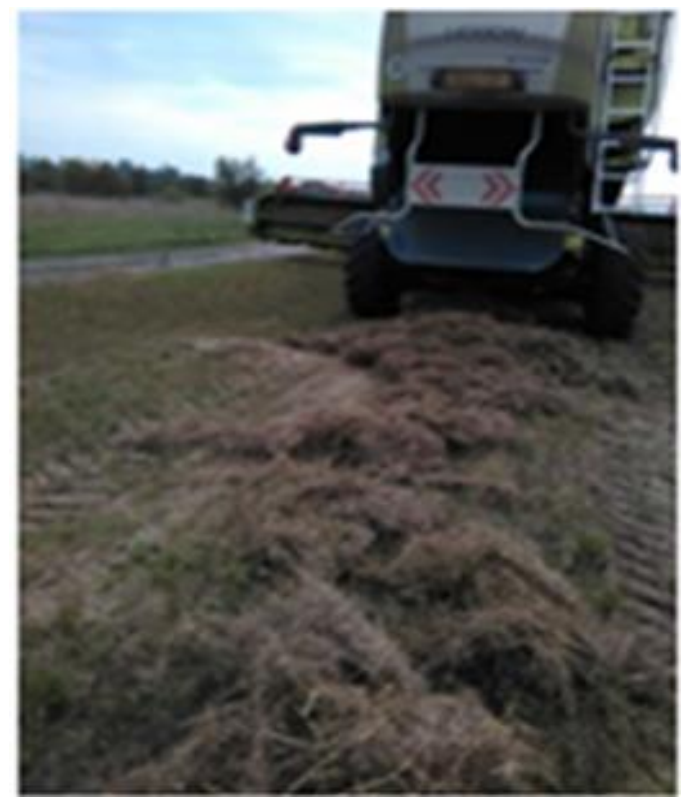

б)

Рис. 2. Валки льону олійного сформовані зернозбиральним комбайном різної фази стиглості: а) - рання жовта стиглість, б) - повна стиглість

Результати визначення комплексного показника якості для волокна зі стебел льону олійного, вирощеного в умовах Західного Полісся у фазі ранньої жовтої стиглості (рис. 2, а) і порівняння з волокном льону-довгунця, вказують на перспективу використання волокна льону олійного у текстильній промисловості [3]. Проте, збирання льону олійного у фазі повної стиглості (рис.2 б) показало на втрату якості стеблової маси (рис. 2, б), відповідно і якості волокна.

Пропонується технологія збирання льону олійного, вирощеного в умовах Західного Полісся [3] яка передбачає можливість врахувати погодні умови у період збирання та забезпечити подальше використання стеблової частини врожаю (рис. 3). 


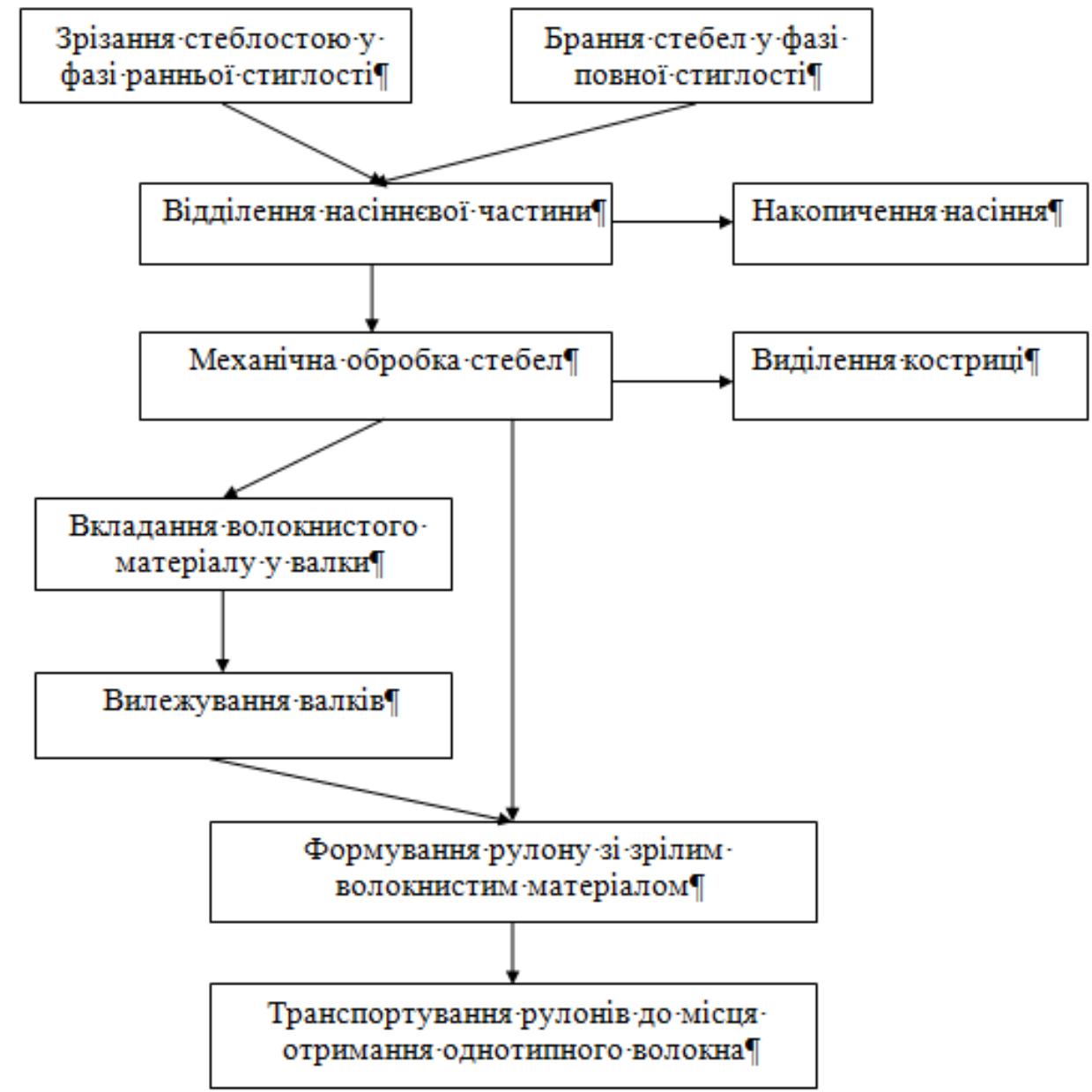

Рис. 3. Запропонована технологія збирання льону з врахуванням фази стиглості

Згідно 3 представленою схемою (рис. 3), отримання однотипного волокнистого матеріалу з льону олійного здійснюється шляхом механічної обробки стебел. При цьому стеблову частину льону зрізують чи беруть залежно від фази стиглості стеблостою, відділяють насіннєву частину та руйнують стебла шляхом механічної обробки, видаляють кострицю, після чого зрілий волокнистий матеріал формують у рулони і транспортують до місця отримання однотипного волокна, а зруйновані стебла у фазі ранньої стиглості вкладають у валки для вилежування. Після вилежування та дозрівання їх волокнистого матеріалу до фази повної стиглості додатковими технічними засобами здійснюють формування рулонів 3 наступним транспортуванням їх до місця отримання однотипного волокна. Механічні дії на стебла полягають у руйнуванні відповідних складових стебла.

Якщо, у першому випадку достатньо зруйнувати поверхневий шар для інтенсивного проникнення вологи у зону розміщення волокон, то у випадку обробки волокнистого матеріалу на стаціонарі, з метою виділення волокна, 
волокнистий матеріал варто подрібнити на частинки, рівні максимально можливій довжині волокна. При цьому необхідно встановити умови його руйнування з врахуванням властивостей структури стебла.

Для ефективного руйнування стеблової частини льону олійного запропоновано механізований засіб з обертовими барабанами (рис. 4, а) [15]. Запропонований пристрій включає розміщені на рамі 1 два основних вузли: шароформувач 2 шару 3 подавального барабану 4, вальцями 3 і 6 та ротор 73 ножами 8 з відповідною робочою поверхнею і типом: молоткового (рис. 4,6 ) чи різального типу (рис. 4 , в).

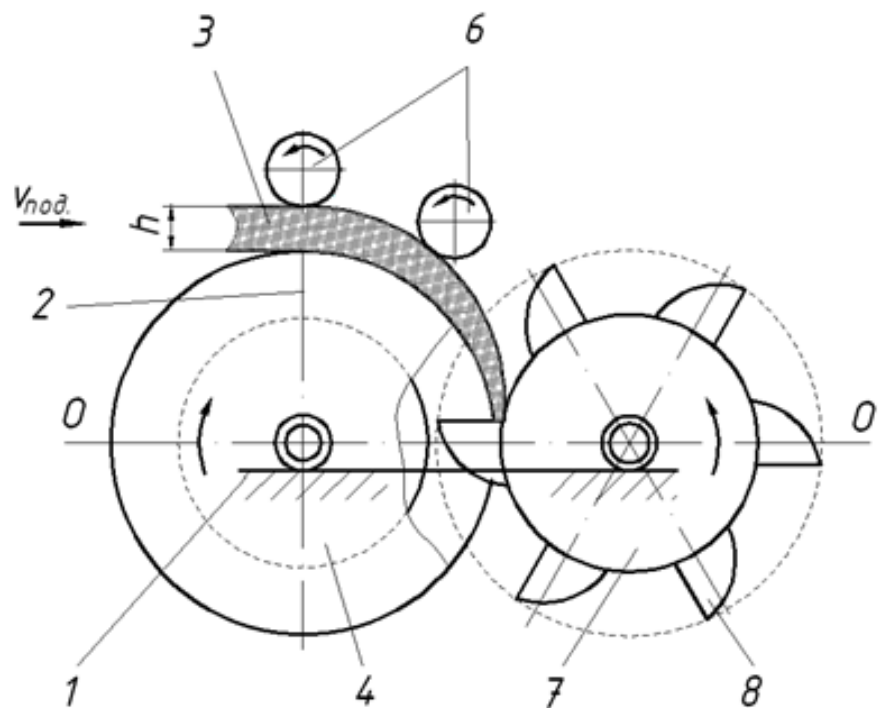

a
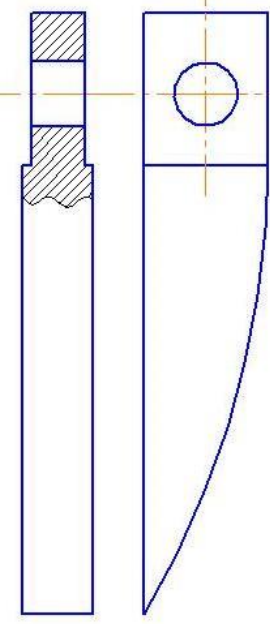

6

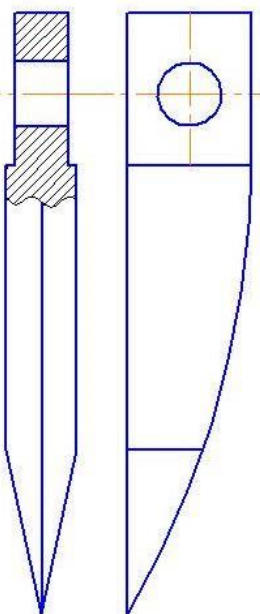

B

Рис. 4. Схема пристрою руйнування стеблової маси: а) загальний вигляд; б, в) типи ножів

Експериментальна перевірка запропонованих типів ножів (рис.4, б, в) довела ефективність руйнування стебел льону олійного з врахуванням фази стиглості та напрямку подальшого використання волокнистої маси. Для зниження пружних властивостей стебел на етапі перетворення їх у тресту необхідно застосовувати ножі молоткового типу (рис. 4, б).

Тоді із стебел частково видаляється костра, а висота валка зменшується у два рази, що сприяє інтенсивному проникненню вологи як 3 поверхні поля, так i 3 оточуючого середовища у поровий простір стебел, забезпечуючи інтенсивний розвиток пектино-руйнівних бактерій.

Для перевірки результатів теоретичних досліджень запропонована лабораторна установка, яка зображена на рис. 5, за допомогою якої вдалось отримати добре подрібнене стебло. 


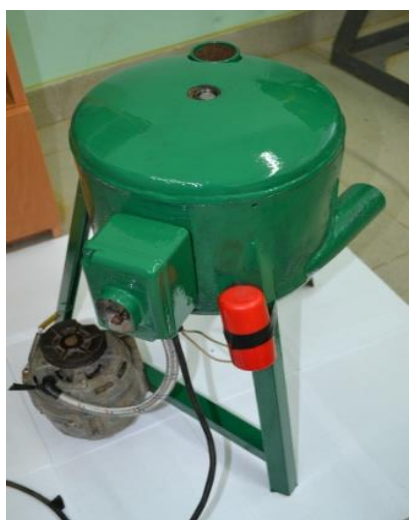

a)

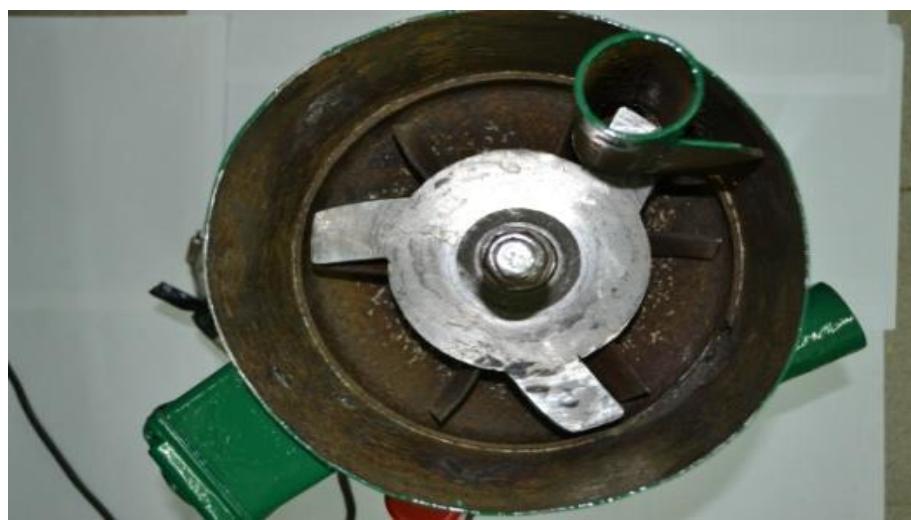

б)

Рис. 5 - Загальний вигляд установки для подрібнення льону олійного(а) та розміщення подрібнюючого пристрою у корпусі (б)

Проведені експериментальні дослідження підтвердили теоретичні розрахунки зі встановлення кута різання стебел льону олійного, який використовується, як у сегментно-пальцевих різальних апаратах, так і в установках для руйнування стеблової маси в процесі його збирання i виділення короткого неорієнтованого волокна. На основі отриманих даних будувались графічні залежності (рис 6, 7).

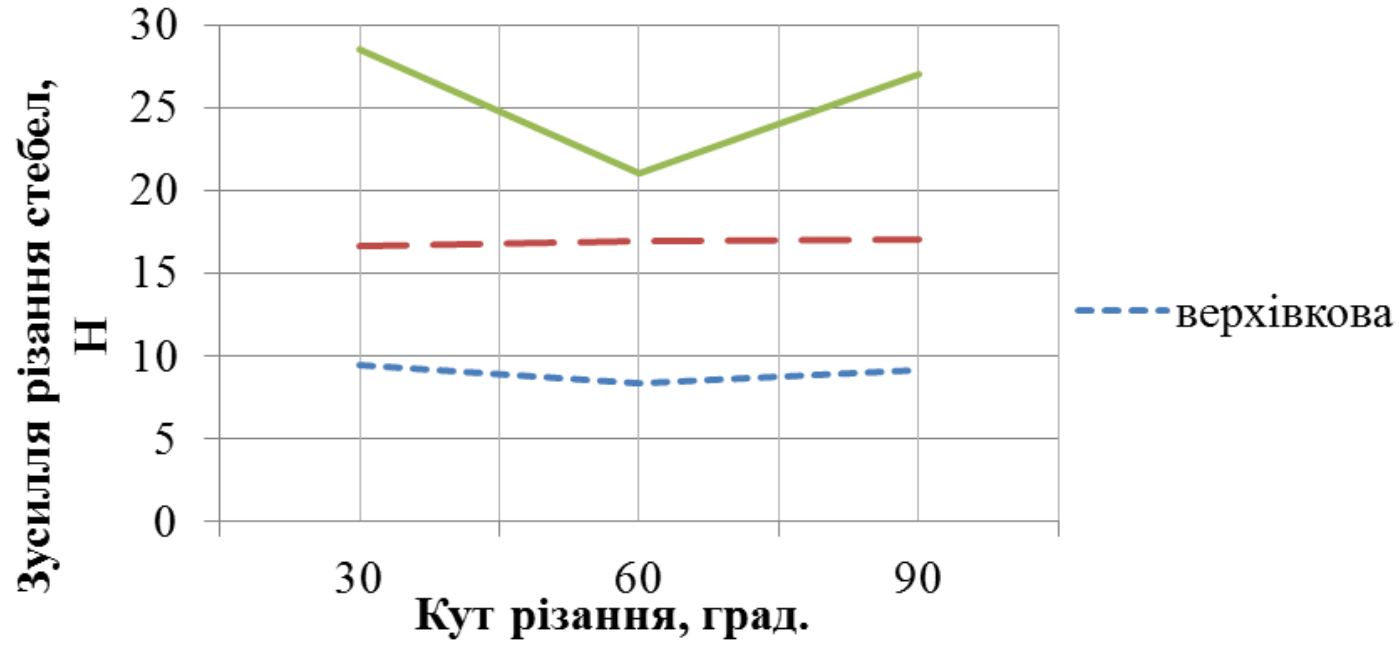

Рис. 6. Залежність зусилля різання стебел льону олійного у стадії жовтої стиглості

Аналіз графіків, представлених на рис. 6 вказують, що використання сегментно - пальцевого різального апарату для збирання льону олійного, важливим $є$ кут різання і він в окоренковій зоні має наближатись до 600 . Досліди вказують, що у фазі повної стиглості кут різання не впливає на прикладення зусилля. При цьому опір різанню стебел в окоренковій частині 
коливається у межах 17,0 Н, середній частині 12,5 H, а у верхівковій $-7,7$ Н. Незначне зусилля вказує на значне зминання стебла. У такому випадку для збирання льону олійного необхідно використовувати бральний апарат.

Тому важливо звернути увагу на зусилля різання трести (рис. 7), яке необхідно знати для подальшої переробки стеблової частини врожаю льону олійного.

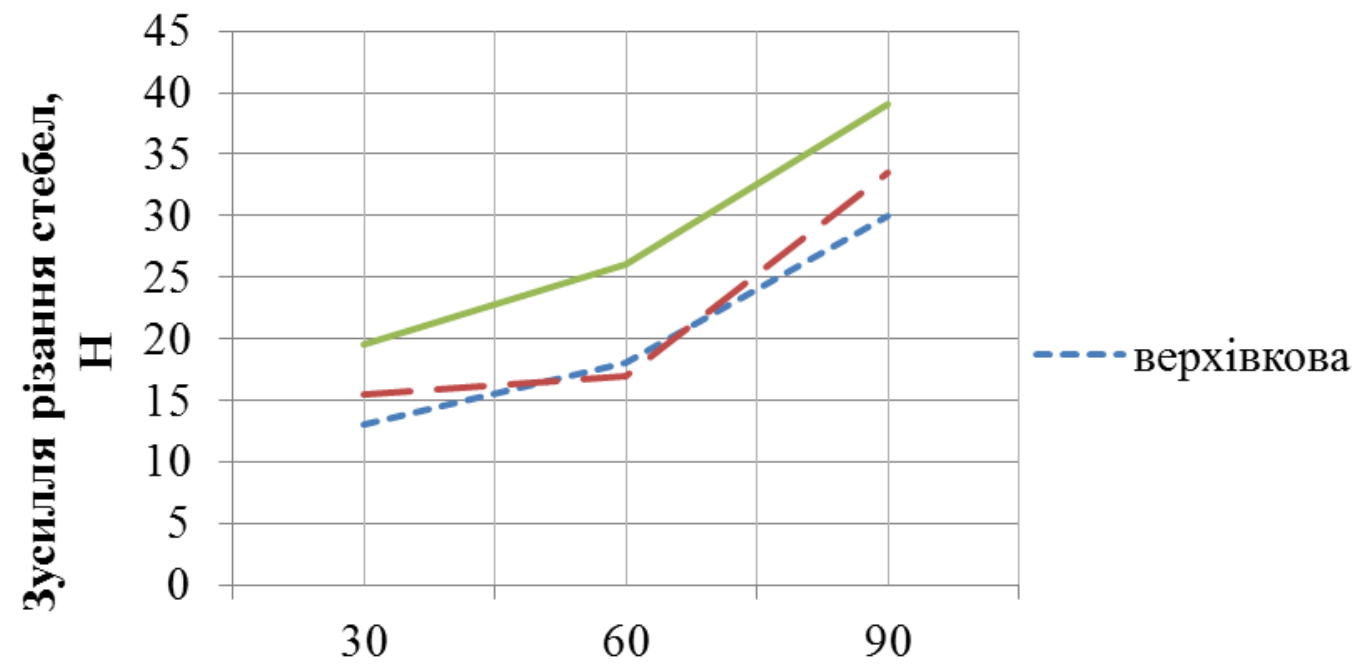

Кут різання, град.

Рис. 7. Залежність зусилля різання трести льону олійного

Тому складність процесу збирання льону олійного у фазі повної стиглості сегментно-пальцевим різальним апаратом ускладнюється з врахуванням даних представлених на рис 7. Із графіків слідує, що раціональним кутом різання у такому випадку $\epsilon$ кут у $30^{\circ}$. Негативним $\epsilon$ також різке зростання зусилля різання за висотою стебла від 13-30 Н до 19,5-42,0 Н, що значно перевищує значення стебел льону олійного у фазі жовтої стиглості.

Таким чином закладений принцип подрібнення стеблової маси льону олійного можна закласти у конструкцію універсального комбайна. Тоді достатньо лише зруйнувати поверхневу частину стебел у фазі ранньої стиглості та, як результат отримати волокно, що придатне для використання у текстильній промисловості. Але, при цьому, на стаціонарі, виділяючи волокно, необхідно додатково подрібнювати соломисту волокнисту масу. У випадку збирання льону олійного у фазі повної стиглості, коли волокно втрачає свої цінні для текстилю властивості, соломисту волокнисту масу можна сформувати у паливні матеріали. Виділені частинки костри на стаціонарі, запропонованим пристроєм (рис. 8) довжиною 3-5 мм можна 
спрямовувати на виробництво паливних брикетів, а волокно середньої довжини 30-50 мм на доочищення з подальшим використанням.

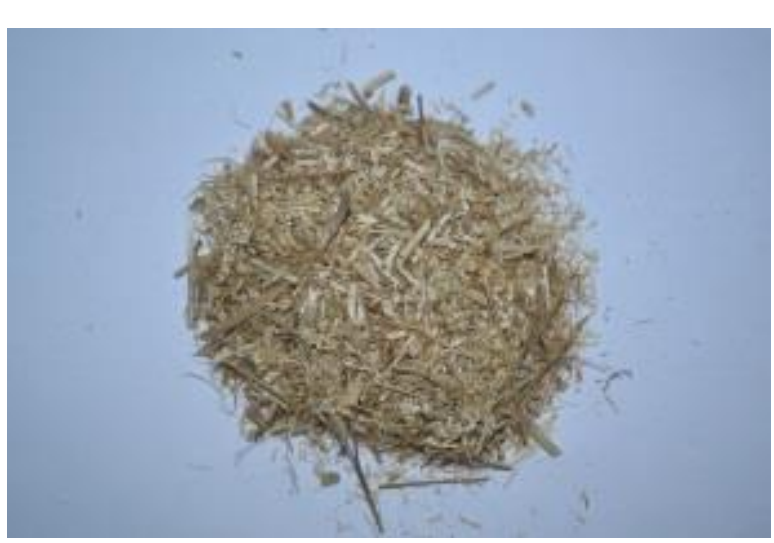

a)

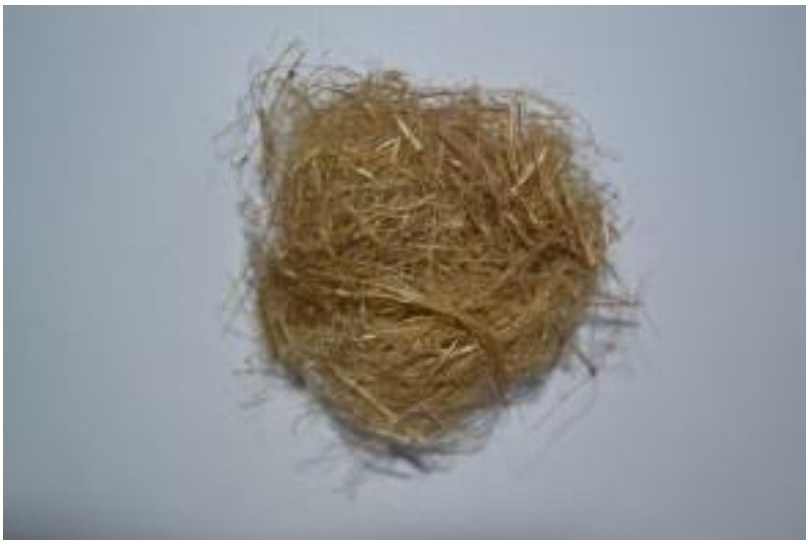

б)

Рис. 8. Складові стеблової частини льону олійного після подрібнення запропонованою установкою: а) костра; б) волокно

Висновки. При науковому підході льон олійний вважається культурою безвідходного виробництва, але для території Західного Полісся перепоною у широкому поширенні льону олійного став високий стеблостій, який може сягати одного метра. Тому отримані результати, що представлені у статті вказують на перспективу застосування комбінованого підходу при використання стеблостою льону олійного. Технології виробництва льону олійного в умовах Західного Полісся $\epsilon$ недосконалими i потребують модернізації операцій збирання 3 метою використання всього потенціалу рослини. Головною проблемою, яка на сьогодні не вирішена, спалювання стебловою частини врожаю. Для збереження вирощеного врожаю, запропоновано технологію збирання льону олійного 3 врахуванням фази стиглості та переробки стебел для подальшого вилежування у тресту або виготовлення паливних матеріалів 3 використанням зернозбирального комбайна удосконаленої конструкції.

Відповідно до погодних умов поточного сезону із стебел можна отримувати якісне коротке неорієнтоване волокно або паливні матеріали циліндричної форми. Для обох випадків обов'язковою є операція руйнування стебел. Проведені експериментальні дослідження підтверджують вибір форми ножів, параметри яких встановлені теоретично.

\section{Список використаних джерел:}

1. Про схвалення розроблених Міністерством екології та природних ресурсів планів імплементації деяких актів законо- давства ЄС [Електронний ресурс]: Розпорядження 
Кабінету Міністрів України від 15.04.2015 № 371-p. — Режим доступу: Iwww/URL: http://zakon5.rada.gov.ua/laws/show/371-2015-p

2. Сай В. А. Удосконалення технології збирання і первинної переробки стеблової частини льону олійного: дис. ...канд.техн. наук: 05.18.01/Сай Володимир Анатолійович. Луцьк,2011. - 194c.

3. Ягелюк С.В. Оцінка якості волокна зі стебел льону олійного, вирощеного в умовах Західного Полісся / Ягелюк С.В., Дідух В.Ф., Онюх Ю.М. // Товарознавчий вісник: Збірник наукових праць. - 2018. - Випуск 11. - С. 167-173

4.Дідора В.Г. Агроекологічне обгрунтування технології виробництва продукції льонудовгунця : монографія / В.Г.Дідора. - Житомир: Вид-во ДВНЗ «Державний агроекологічний університет», 2008. - 411 с.

5. Голуб И.А. Льноводство Белоруси /И.А. Голуб, А.З. Чернушок // РУП «Ин-т льна Нац. акад. Белоруси». - Борисов: Борисов. укруп. тип. им. 1 Мая, 2009. - 245 с.

6. Чурсіна Л.А. Наукові основи комплексної переробки стебел та насіння льону олійного / Л.А.Чурсіна, Г.А. Тіхосова, О.О.Горач, Т.І.Янюк. Херсон:Олді - плюс, 2011. $356 \mathrm{c}$.

7. Дідух В.Ф. Технологія переробки стеблової маси льону олійного, отриманої в умовах Західного Полісся / В.Ф. Дідух, Дуць І.З., Ягелюк С.В., Онюх Ю.М., Бойчук Б.В. // Зб. наук. статей «Сільськогосподарські машини». - Вип. 38. - С. 55 - 60.

8. Лопотко М.З. Сапропели и продукты на их основе / Лопотко М.3., Евдокимова Г.А. - Мн.: Наука и техника, 1986. - 191 с.

9. ДСТУ-П CEN/TS 15210-2:2009. Технічні умови. Паливо з відходів деревини, сільськогосподарських культур гранульоване та брикетоване

10. Дідух В.Ф. Визначення властивостей паливних матеріалів сформованих з стебел льону олійного / Дідух В.Ф., Тарасюк В.В., Оніщук А.С., Соколовський В.І. // Сільськогосподарські машини. - 2016. - № 35. - С. 16-23.

11. Дідух В.Ф. Лабораторно експериментальна установка для виготовлення паливних брикетів / В.Ф. Дідух, В.В. Том’юк, В.І. Чучман // Вчені Львівського національного аграрного університету виробництву: Каталог інноваційних розробок. Вип. XV. Львів : Львівський національний аграрний університет, 2015.

12.Лісовий I.О. Енергетика процесу перерізання рослинних решток комбінованим сошником для прямого посіву. / I.О. Лісовий, А.І. Бойко, М.О. Свірень, В.А. Пашинський // Конструювання, виробництво та експлуатація сільськогосподарських машин: Загальнодержавн. міжвідомч. наук.-техн. зб. - Кіровоград : КНТУ, 2012. - Вип.42, Ч.1. C.75- 81 .

13 Завірюха М.В. Теоретичні дослідження роботи інтегрованого різального апарату / Завірюха М.В. // Вісник Львівського національного аграрного університету. Серія: Технічні науки. - Львів: Видавництво ЛНАУ, 2012. - 341 с.

14.Труш М.М. Визначення характеристик подрібнювача рослинних решток в лабораторних умовах / Труш М.М., Солових Є.К., Аулін В.В. // Вісник ХДТУСГ. - Харків : Вид-во ХДТУСГ. - 2004. - Вип. 23. - С. 68 - 71.

15. Патент на корисну модель №121747, МПК D01B1/00. Пристрій для розмотування та подрібнення луб’яної сировини. / Дідух В.Ф., Кірчук Р.В., Онюх Ю.М., Ягелюк С.В.; заявник і власник Луцький НТУ. - u201707177; заяв. 11.12.2017; опуб.11.12.2017p., Бюл. № 23.

Цель. Установить возможность использования стеблевой части урожая льна масличного, выращенного в природно-климатических условиях Западного Полесья для повышения эффективности и экологической безопасности ее утилизации. 
Методика. Для исследований использовали аналитические и расчетные методы. Значения показателей получены экспериментально $c$ помощью современных измерительных средств в соответствии с действующими нормативно-техническими документами.

Результаты. $\quad$ с статье показаны основные результаты теоретикоэкспериментальных исследований прочессов сбора и переработки стеблевой части урожая льна масличного. Предложен алгоритм, описывающий технологический процесс сбора льна масличного с учетом фазы его зрелости и погодных условий, влияющих на выбор способа сбора и дальнейшего использования стеблевой части урожая.

При научном подходе лен масличный считается культурой безотходного производства, но для территории Западного Полесья преградой в широком распространении льна масличного стал высокий стеблестой, который может достигать одного метра. Технологии производства льна масличного в условиях Западного Полесья несовершенны и нуждаются в модернизации операџий сбор с иелью использования всего потенциала растения. Главной проблемой, которая на сегодняшний день не решена является сжигание стеблевой части урожая. Для сохранения выращенного урожая, предложена технология сбора льна масличного с учетом фазы зрелости и переработки стеблей для дальнейшего лежания в треста или изготовления топливных материалов с использованием зерноуборочного комбайна усовершенствованной конструкции.

Оиенка потребительских свойств волокна льна масличного указывает на значительный его потенциал, как сырья для текстильной промышленности. Однако, сложности, возникающие при вылеживании стеблей в тресту, требуют поиска новых направлений использования волокнистой массы, которая формируется в прочессе сбора льна масличного зерноуборочным комбайном. В соответствии с погодными условиями сбора и первичной переработки в текущем сезоне и в условиях Западного Полесья из стеблей льна масличного можно получать качественное короткое неориентированное волокно или топливные материаль ичилндрической формы. Для обоих случаев обязательна операчия разрушения стеблей.

Научная новизна. Предложено адаптированную $\kappa$ природно-климатическим условиям Западного Полесья технологию комплексной переработки биологического потенциала льна масличного для получения товаров различного фунниионального назначения.

Практическая значимость. Предложенная технология позволит повысить эффективность использования льна масличного в условиях Западного Полесья $и$ удовлетворит экологические требования.

Ключевые слова: лен масличный, стебли, волокно, климатические условия, усилие резания, разрушения, технологии, технические средства.

Goal. To establish the possibility of using the stem portion of the flaxseed crop grown in the climatic conditions of the Western Polesie in order to increase the efficiency and environmental safety of its utilization.

Method. For research, analytical and calculation methods were used. The values of the indicators are obtained experimentally with the help of modern measuring instruments in accordance with the current normative and technical documents.

Results. The article shows the main results of theoretical and experimental studies of the processes of gathering and processing of the stem portion of oilseed flax crop. An algorithm describing the technological process of collecting flaxseed oil is proposed taking into account the phase of its maturity and weather conditions, which influence the choice of the method of collection and further use of the stem portion of the crop. 
In the scientific approach, flax is considered to be a culture of non-waste production, but for the territory of Western Polesie the barrier in the widespread distribution of flax has become a high stem, which can reach one meter. The production of flax in the conditions of Western Polessie is imperfect and requires the modernization of operations collection to use the full potential of the plant. The main problem, which is not solved to date, is the burning of the stem portion of the crop. To preserve the crop, a technology of collecting flax with the maturity phase and processing of the stems for further in the textile or the manufacture of fuel materials with the use of a combine harvester of an improved design was proposed.

Estimation of the consumer properties of flax indicates its significant potential as raw material for the textile industry. However, the difficulties encountered in trimming the stems require the search for new directions for the use of fiber mass, which is formed during the flax harvesting with a seed combine harvester. In accordance with the weather conditions of collection and primary processing in this season and in the conditions of Western Polesie, from the flax stems it is possible to obtain qualitative short, unoriented fiber or fuel materials of a cylindrical shape. For both cases, an operation is required to destroy the stems.

Novelty. The Technology of Integrated Processing of the biological potential of OilseedFlax for the production of goods of various functional purposes was proposed adapted to the naturalclimatic conditions of Western Polessye.

Practical significance. The proposed Technology $f$ Integrated Processing will increase the efficiency of using oilseed flax in the conditions of Western Polesie and will satisfy the ecological requirements.

Key words: oil flax, stalks, fiber, climatic conditions, cutting force, destruction, technologies, technical means.

Стаття рекомендована до публікаиії доктором технічних наук, професором Байдаковою Л.І. Дата надходження в редакиію 10.12.2018 p. 